\title{
Article \\ Constitutive Expression in Komagataella phaffii of Mature Rhizopus oryzae Lipase Jointly with Its Truncated Prosequence Improves Production and the Biocatalyst Operational Stability
}

\author{
Josu López-Fernández (D), Maria Dolors Benaiges and Francisco Valero *(D) \\ Department of Chemical, Biological and Environmental Engineering, School of Engineering, \\ Universitat Autònoma de Barcelona, Bellaterra, 08193 Barcelona, Spain; josu.lopez@uab.cat (J.L.-F.); \\ mariadolors.Benaiges@uab.cat (M.D.B.) \\ * Correspondence: francisco.valero@uab.cat; Tel.: +34-93-5811809
}

\section{check for}

updates

Citation: López-Fernández, J.; Benaiges, M.D.; Valero, F.

Constitutive Expression in

Komagataella phaffii of Mature Rhizopus

oryzae Lipase Jointly with Its

Truncated Prosequence Improves

Production and the Biocatalyst

Operational Stability. Catalysts 2021

11, 1192. https://doi.org/10.3390/

catal11101192

Academic Editor: Zheng Guo

Received: 12 September 2021

Accepted: 29 September 2021

Published: 30 September 2021

Publisher's Note: MDPI stays neutral with regard to jurisdictional claims in published maps and institutional affiliations.

Copyright: (c) 2021 by the authors. Licensee MDPI, Basel, Switzerland. This article is an open access article distributed under the terms and conditions of the Creative Commons Attribution (CC BY) license (https:// creativecommons.org/licenses/by/ $4.0 /)$.
Abstract: Rhizopus oryzae lipase (ROL) containing 28 C-terminal amino acids of the prosequence fused to the $\mathrm{N}$-terminal mature sequence in ROL (proROL) was successfully expressed in the methylotrophic yeast Komagataella phaffii (Pichia pastoris) under the constitutive glyceraldehyde-3-phosphate dehydrogenase promoter $\left(\mathrm{P}_{G A P}\right)$. Although the sequence encoding the mature lipase (rROL) was also transformed, no clones were obtained after three transformation cycles, which highlights the importance of the truncated prosequence to obtain viable transformed clones. Batch cultures of the K. phaffii strain constitutively expressing proROL scarcely influenced growth rate and exhibited a final activity and volumetric productivity more than six times higher than those obtained with proROL from $K$. phaffii under the methanol-inducible alcohol oxidase 1 promoter $\left(\mathrm{P}_{A O X 1}\right)$. The previous differences were less marked in fed-batch cultures. N-terminal analysis confirmed the presence of the 28 amino acids in proROL. In addition, immobilized proROL exhibited increased tolerance of organic solvents and an operational stability 0.25 and 3 times higher than that of immobilized rROL in biodiesel and ethyl butyrate production, respectively. Therefore, the truncated prosequence enables constitutive proROL production, boosts bioprocess performance and provides a more stable biocatalyst in two reactions in which lipases are mostly used at industrial level, esterification (ethyl butyrate) and transesterification (biodiesel).

Keywords: Rhizopus oryzae lipase; Komagataella phaffii; prosequence; flavor; biodiesel; biocatalysis

\section{Introduction}

Biocatalysis has for some time been extensively used to obtain a variety of products including polymers, fine and bulk chemicals, flavors and pharmaceutical intermediates [1,2]. Lipases (triacylglycerol hydrolases E.C. 3.1.1.3), which are the most widely used biocatalysts after proteases and amylases, catalyze a wide range of industrially interesting reactions including esterification, transesterification and interesterification [3,4]. Specifically, $R h i-$ zopus oryzae lipase (ROL) has been the subject of much study on account of a number of favorable traits such as 1,3-regioespecificity, high thermostability, tolerance of organic solvents, and the ability to produce flavors, biodiesel and structured lipids [5]. All lipases from the genus Rhizopus are synthesized as precursor forms sharing a common structure. Thus, ROL forms from a presequence of 26 amino acids that is followed by a prosequence of 97 and a mature sequence of 269 [6]. Whereas the presequence is known to act as a signal peptide, the specific functions of the prosequence are incompletely known but thought to include increasing protein stability, reducing stress during recombinant protein expression, and minimizing unfolded protein response (UPR) in rROL production-which has an adverse impact on microbial growth [7-9]. Obtaining the mature form of the lipase (rROL) entails removing the presequence and prosequence $[10,11]$. However, the native microorganism secretes a protein including the mature sequence and, attached to its N-terminal, 
the $28 \mathrm{C}$-terminal amino acids of the prosequence (proROL), which are subsequently proteolyzed by extracellular proteases. The 28 amino acids by themselves seemingly suffice for the previous positive traits of the whole prosequence to occur and are thus important with a view to developing a potentially improved ROL-based biocatalyst [7].

The industrial use of enzymes is often hampered by their high cost and also, often, by their low thermostability and poor tolerance of organic solvents. These shortcomings are usually circumvented by immobilization or heterologous production [12,13]. Immobilization facilitates the recycling of biocatalysts and usually increases their stability. Enzymes are typically immobilized by binding to a support, entrapment or cross-linking [14,15]. ROL can be effectively immobilized in these three ways (e.g., by adsorption [16], covalent binding [17], entrapment into alginate beads [18] or formation of cross-linked aggregates [19]). Immobilized biocatalysts have proved highly suitable for industrial-scale applications such as biodiesel and flavor production [5].

Heterologous production of enzymes is a more efficient and economical method than using native microorganisms [20]. ROL has been obtained to date from the well-known cell factories Escherichia coli, Saccharomyces cerevisiae and Komagataella phaffii (Pichia pastoris). In E. coli, however, the presence of three disulfide bonds in the protein, and the absence of suitable enzymes for maturation of fungal lipases, leads to the production of inactive lipase [21]. Nevertheless, by using the E. coli Origami (DE3) strain and pET-11d expression system, Di Lorenzo et al. succeeded in obtaining two ROL forms containing the mature sequence alone and the whole prosequence as well [22]. However, even if the soluble and active production of lipases was achieved, the fact that the enzymes were intracellularly produced-therefore requiring further purification steps-as well as the lack of protein processing mechanisms, since the lipase that contained the complete prosequence was not properly hydrolyzed, promoted the assessment of the yeasts S. cerevisiae and K. phaffii as potential sources for this enzyme. The different proteolytic processing imposed by Kex2-like protease in S. cerevisiae enabled the production of two lipase forms by the gene encoding the whole prosequence linked to the mature sequence (w-proROL-gene), unlike observed with E. coli; however, no activity was detected when only the mature sequence gene (rROL-gene) was expressed, which highlights the importance of the prosequence for efficient production of the lipase [5]. With the methylotrophic yeast K. phaffii, only the cleaved form of ROL was obtained after w-proROL-gene expression, which underlies the increased activity of Kex2-like protease in this microorganism [23]. In addition, unlike S. cerevisiae, K. phaffii expressed rROL-gene [24], which led to K. phaffii being deemed the best host for ROL heterologous production. This yeast has been reported to possess a number of advantages such as the absence of endogenous esterases or lipases, and the ability to secrete heterologous proteins, enact eukaryotic post-translational modifications and grow at high cell densities (ca. $100 \mathrm{~g} \mathrm{~L}^{-1}$ dry cell weight) in some media [25,26].

The alcohol oxidase 1 promoter $\left(\mathrm{P}_{A O X 1}\right)$ has been extensively used to express ROL in K. phaffii. This promoter is strongly induced by methanol but repressed by glucose and glycerol. Although $\mathrm{P}_{A O X 1}$ allows large amounts of protein to be obtained, the use of methanol increases oxygen requirements and heat production-and raises production costs through the need to store and handle methanol properly $[27,28]$. These drawbacks have prompted the use of methanol-independent promoters such as the constitutive glyceraldehyde-3phosphate dehydrogenase promoter $\left(\mathrm{P}_{G A P}\right)$ from central carbon metabolism [29]. Despite the constitutive nature of $\mathrm{P}_{G A P}$, its strong expression capacity depends on the carbon source and growth rate of the particular culture $[30,31]$. Although the expression of ROL has been already reported under this constitutive promoter, w-proROL-gene, which encodes both the prosequence and the mature sequence, is needed to alleviate the adverse effects of producing the mature sequence of ROL under $\mathrm{P}_{G A P}$ [32], as this lipase form is harmful to the host cell [10]. In fact, rROL-gene expression has only been accomplished under the inducible $\mathrm{P}_{A O X 1}[7,33]$-inducible promoters are less troublesome than constitutive promoters in this respect [34]. 
The primary aim of this work was to express ROL under the constitutive promoter $P_{G A P}$ by using the 28 amino acids of its prosequence fused to the mature sequence to enable a methanol-independent and more environmentally friendly bioprocess. The alleged positive traits of the $28 \mathrm{C}$-terminal amino acids of the prosequence were assessed in terms of reducing the impact on host strain growth, increasing bioprocess productivity, improving the stability of the immobilized biocatalyst against organic solvents and boosting its operational stability during biodiesel and ethyl butyrate (pineapple flavor) production.

\section{Results and Discussion}

\subsection{Batch and Fed-Batch Bioprocess Strategies. Lipase Production under Inducible $P_{A O X 1}$ and Constitutive $P_{G A P}$}

The fact that some of the positive traits of the whole prosequence have also been identified with truncated sequences [21,35], led us to transform K. phaffii with proROL $\mathrm{P}_{G A P}$-plasmid, rROL $\mathrm{P}_{\mathrm{GAP}}$-plasmid and the empty plasmid-blank - to investigate the role of the C-terminal 28 amino acids of the prosequence.

Three transformation runs with each plasmid produced 252 colonies with the blank and 21 with proROL $P_{G A P}$-plasmid but none with rROL $P_{G A P}$-plasmid. Based on this outcome, the ROL mature sequence must somehow hinder constitutive expression in K. phaffii. In fact, these results are consistent with those of previous work where production of the ROL mature sequence caused cell lysis in E. coli owing to its phospholipase activity but no lysis when $28 \mathrm{C}$-terminal amino acids in the prosequence were expressed together with the mature sequence, although noxious effects were still observed as cell growth was inhibited [10]. Consequently, the truncated prosequence of ROL (28 C-terminal amino acids) can be assumed to alleviate the deleterious effects of the lipase and enable production of viable clones of $K$. phaffii as a result.

Viable clones expressing proROL were identified by colony PCR and a pool of positive colonies was selected as described in Section 3.2, the most productive clone being chosen for further testing. Single plasmid integration in the proROL $P_{G A P}$-strain clone was confirmed by ddPCR and duplicate batch cultures were run with glycerol as carbon source.

Key production and growth parameters were compared with reported values for

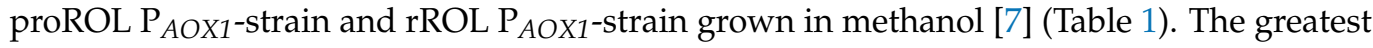
differences between proROL $\mathrm{P}_{A O X 1}$-strain and proROL $\mathrm{P}_{G A P}$-strain were those in final activity and volumetric productivity, which were 6.5 times higher in the latter. Additionally, $q_{\mathrm{p}}$ was 2.2 times higher with proROL $\mathrm{P}_{G A P}$-strain than it was with proROL $\mathrm{P}_{A O X 1}$-strain. However, $Y_{(\mathrm{P} / \mathrm{X})}$ was greater with the latter than it was with the former. In line with these results, specific productivities were very similar with both strains. In fact, the increased $Y_{(\mathrm{P} / \mathrm{X})}$ value obtained with proROL $\mathrm{P}_{A O X 1}$-strain was offset by the increased specific growth rate of proROL $P_{G A P}$-strain, which reduced bioprocess operation time.

Table 1. Results obtained in batch tests involving proROL $\mathrm{P}_{A O X 1}$-strain and rROL $\mathrm{P}_{A O X 1}$-strain in

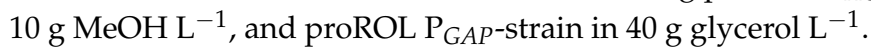

\begin{tabular}{|c|c|c|c|}
\hline Parameter & proROL $P_{A O X 1}{ }^{1}$ & proROL $P_{G A P}$ & $\operatorname{rROL} P_{A O X 1}{ }^{1}$ \\
\hline Final activity $\left(\mathrm{AU} \mathrm{mL^{-1 }}\right)$ & 12.38 & 74.71 & 10.51 \\
\hline $\mathrm{Y}_{(\mathrm{P} / \mathrm{X})}\left(\right.$ total AU total $\left.\mathrm{g}_{\mathrm{X}}{ }^{-1}\right)$ & 5017 & 4273 & 3753 \\
\hline$\mu\left(\mathrm{h}^{-1}\right)$ & 0.073 & 0.22 & 0.045 \\
\hline$q_{\mathrm{p}}\left(\mathrm{AU} \mathrm{gx} \mathrm{g}^{-1} \mathrm{~h}^{-1}\right)$ & 391 & 874 & 168 \\
\hline Specific productivity $\left(\mathrm{AU} \mathrm{g}_{\mathrm{X}}^{-1} \mathrm{~h}^{-1}\right)$ & 195 & 192 & 139 \\
\hline Volumetric productivity $\left(\mathrm{AU} \mathrm{L}^{-1} \mathrm{~h}^{-1}\right)$ & 462 & 3367 & 389 \\
\hline
\end{tabular}

${ }^{1}$ Data obtained from [7].

The truncated prosequence minimized the harmful effects of mature ROL production on K. phaffii growth, no matter the promoter employed (Table 1). In fact, growth rates with proROL-producing strains were similar to those of wild-type strain under both glycerol $\left(0.22 \mathrm{~h}^{-1}\right.$ with proROL $\mathrm{P}_{G A P}$-strain and $0.25 \mathrm{~h}^{-1}$ with the wild-type strain) and methanol

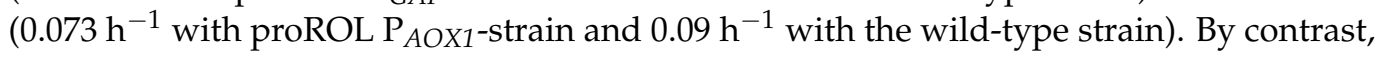


the growth rate of rROL $\mathrm{P}_{A O X 1}$-strain in methanol was markedly lower $\left(0.045 \mathrm{~h}^{-1}\right)$. These results suggest that $K$. phaffii is an effective cell factory for ROL production; as unlike above described with $E$. coli, in which proROL expression inhibited cell growth [10].

proROL $\mathrm{P}_{G A P}$-strain was also grown in fed-batch cultures, using a pre-programmed exponential glucose feeding rate to maintain a constant specific growth rate of $0.045 \mathrm{~h}^{-1}$. Various key bioprocess parameters for proROL $\mathrm{P}_{G A P}$-strain were determined for comparison with previously reported results (Table 2) by using proROL $\mathrm{P}_{A O X 1}$-strain and the methanol limited fed-batch (MLFB) strategy at a constant specific growth rate, and the methanol non-limited fed-batch (MNLFB) strategy at a constant methanol concentration of $3 \mathrm{~g} \mathrm{~L}^{-1}$ in the culture broth throughout the induction stage. Based on previously obtained evidence, the latter is the more suitable strategy with this production system [7].

Table 2. Results obtained with proROL $\mathrm{P}_{G A P}$-strain under carbon-limited fed-batch conditions, and also with proROL $\mathrm{P}_{A O X 1}$-strain under either methanol-limited fed-batch (MLFB) conditions at a preset specific growth rate of $0.045 \mathrm{~h}^{-1}$ or methanol non-limited fed-batch (MNLFB) conditions at a constant methanol concentration of $3 \mathrm{~g} \mathrm{~L}^{-1}$.

\begin{tabular}{|c|c|c|c|}
\hline \multirow[b]{2}{*}{ Parameter } & \multicolumn{2}{|c|}{$\begin{array}{c}\text { Carbon-Limited Fed-Batch } \\
\mu_{\text {set-point }}=0.045 \mathrm{~h}^{-1}\end{array}$} & \multirow{2}{*}{$\begin{array}{c}\text { MNLFB } \\
3 \mathrm{~g} \mathrm{~L}^{-1} \\
\text { proROL } \\
P_{A O X 1}{ }^{1}\end{array}$} \\
\hline & proROL $P_{A O X 1}{ }^{1}$ & proROL $P_{G A P}$ & \\
\hline Final activity $\left(\mathrm{AU} \mathrm{mL}^{-1}\right)$ & 147 & 341 & 358 \\
\hline $\mathrm{Y}_{(\mathrm{P} / \mathrm{X})}\left(\right.$ total AU total $\left.\mathrm{g}_{\mathrm{X}}{ }^{-1}\right)$ & 1908 & 6789 & 4972 \\
\hline Estimated $\mu\left(\mathrm{h}^{-1}\right)$ & 0.038 & 0.045 & 0.065 \\
\hline$q_{\mathrm{p}}\left(\mathrm{AU} \mathrm{gx}^{-1} \mathrm{~h}^{-1}\right)$ & 68.5 & 479 & 308 \\
\hline Specific productivity $\left(\mathrm{AU} \mathrm{g}_{\mathrm{X}}^{-1} \mathrm{~h}^{-1}\right)$ & 44 & 156 & 99 \\
\hline Volumetric productivity $\left(\mathrm{AU} \mathrm{L}^{-1} \mathrm{~h}^{-1}\right)$ & 2782 & 7881 & 7160 \\
\hline
\end{tabular}

${ }^{1}$ Data obtained from [7].

As in the batch cultures, final activity (Figure 1) and volumetric productivity (Table 2) with proROL $\mathrm{P}_{G A P}$-strain and the fed-batch strategy were higher than with proROL $\mathrm{P}_{A O X 1^{-}}$ strain grown under carbon-limited fed-batch conditions at a similar specific growth rate [7]. However, $Y_{(\mathrm{P} / \mathrm{X})}$ was greater with proROL $\mathrm{P}_{G A P}$-strain than it was with proROL $\mathrm{P}_{A O X 1^{-}}$ strain, contrary to what was observed during batch cultures. This outcome is consistent with the results of previous work were the MLFB strategy was reported to perform poorly [36].

Interestingly, $Y_{(\mathrm{P} / \mathrm{X})}$ under MNLFB was 1.5 times higher with proROL $\mathrm{P}_{\mathrm{GAP}}$-strain than it was with proROL $\mathrm{P}_{A O X 1}$-strain. However, final activity and volumetric productivity were similar with both strains. Thus, the bioprocess parameters for proROL $\mathrm{P}_{G A P}$-strain grown at specific rate of $0.045 \mathrm{~h}^{-1}$ on glucose were similar to those provided by proROL $\mathrm{P}_{A O X 1}$-strain with the best strategy devised so far. Therefore, this strategy not only enables methanol-free proROL production but also lends itself readily to bioprocess optimization with proROL $\mathrm{P}_{\mathrm{GAP}}$-strain. 


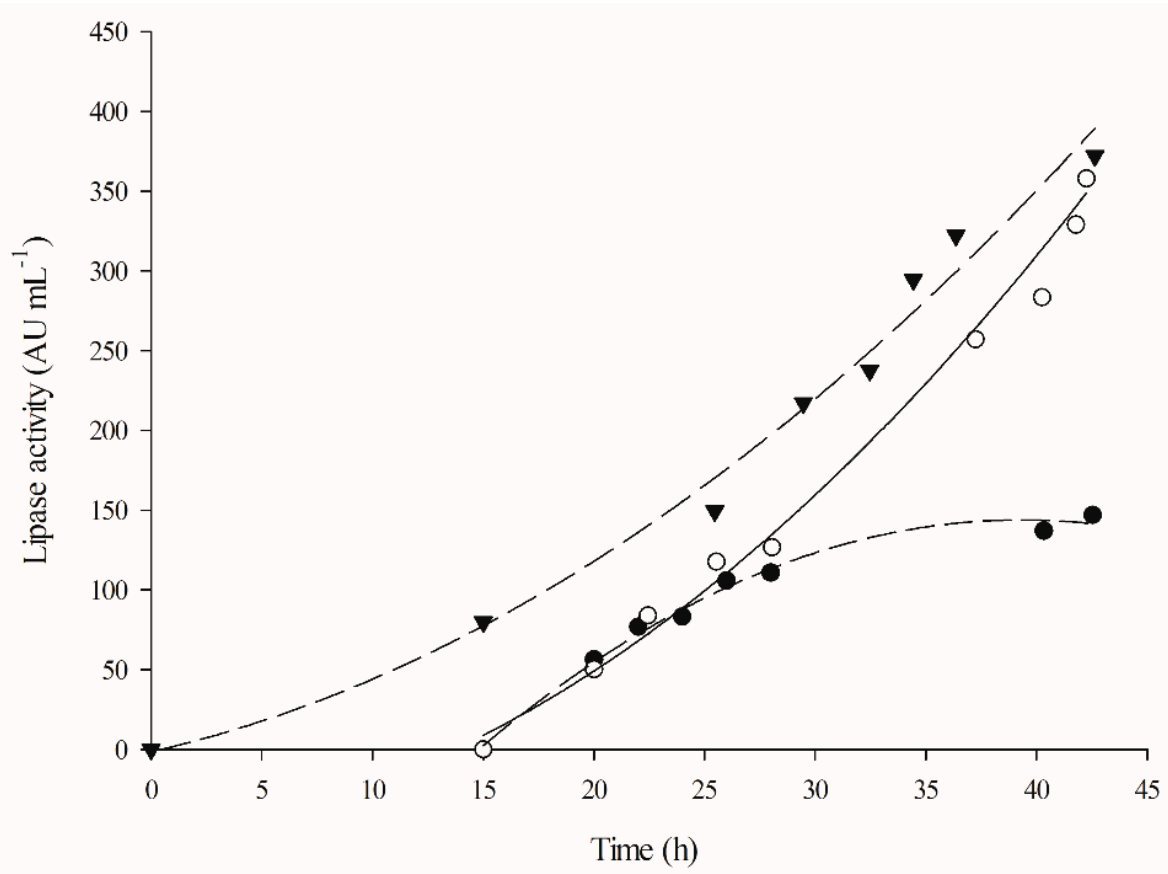

Figure 1. Time course of lipase activity in carbon limited fed-batch cultures of proROL $P_{G A P}$-strain and proROL $\mathrm{P}_{A O X 1}$-strain at a preset specific growth rate of $0.045 \mathrm{~h}^{-1}$ (dashed line) and with MNLFB (solid line). Strains: proROL $\mathrm{P}_{A O X 1}$ (circles) and proROL $\mathrm{P}_{G A P}$ (triangles).

\subsection{N-Terminal Amino Acids in proROL, rROL and proROLm Free Enzymes}

Previous results obtained by SDS-PAGE molecular weight analysis suggested selective proteolysis of the N-terminal 28 amino acids in the truncated prosequence of proROL by effect of proteases [7]. Similar results were also obtained with $R$. niveus lipase, whose $\mathrm{N}$-terminal is identical with that of ROL [37]. Therefore, these 28 amino acids seem to be naturally designed for removal to obtain the lipase mature sequence (rROL). proROL behaved identically here. The qualitative information of proteolysis obtained by SDS-PAGE technique was confirmed by $\mathrm{N}$-terminal sequence analysis, which involved automated Edman's degradation of proROLm (proteolyzed proROL, see Section 3.5), and comparison with proROL and rROL N-terminal (Table 3). The 28 amino acids in the prosequence were confirmed to be primarily hydrolyzed by proteases in order to convert proROL into the lipase mature sequence (rROL). However, the expected proROLm sequence, which should have been identical with that of rROL, did not materialize because the first serine was removed. Based on studies done with the bioinformatic tool Expasy, the digestion pattern could be ascribed to AspN and AspGluN endoproteases.

Table 3. Expected sequence for the $\mathrm{N}$-terminal based on the cloned sequence and actual sequence as determined by Edman's degradation analysis.

\begin{tabular}{ccc}
\hline Enzyme & Expected Sequence & Actual Sequence \\
\hline proROL & DDNLVG & EADDNL \\
\hline proROLm $^{1}$ & SDGGKVV & DGGKVV \\
\hline rROL $^{1}$ & SDGGKVV & EAEFSDGGKVVAA \\
\hline
\end{tabular}

${ }^{1}$ Data obtained from [38].

Regarding proROL N-terminal, as previously reported for rROL [38], the plasmid used for heterologous production of the lipase in K. phaffii left the last two amino acids of the alpha-factor sequence of S. cerevisiae (EA) in the resulting protein. The presence of these amino acids is important because the theoretical isoelectric point $(\mathrm{p} I)$ for proROL as calculated with Expasy bioinformatic tool switches from 6.32 to 6.08, which explains 
previously encountered turbidity issues in proROL strain fermentations at $\mathrm{pH}$ 5.5-a value near the $\mathrm{p} I$ level leading to enzyme denaturation [7]. In addition, unlike in rROL [38], the following two amino acids, EF-an unwanted sequence coming from the restriction site-were not found because plasmid restriction sites were upgraded. Then, in addition to the EA amino acids, proROL N-terminal showed the same sequence as native lipase from Rhizopus oryzae (indicated in Table 3 as the expected sequence) [39]. This outcome might explain that in previous work, proROL and the native ROL showed similar substrate specificity towards $p$-nitrophenol esters of different chain length [7].

\subsection{Stability of EB-proROL and EB-rROL in the Presence of Organic Solvents}

For industrial use, biocatalysts must be stable enough in the organic solvents typically used [40]. ROL has been deemed tolerant of non-aqueous solvents [41]. However, because proROL is a more stable enzyme than $\mathrm{rROL}$ by virtue of its truncated prosequence [21], in this work we compared the stability of both lipases covalently immobilized onto a support containing epoxy and butyl functional groups (EB) in solvents spanning a wide range of $\log p$ values (Figure 2).

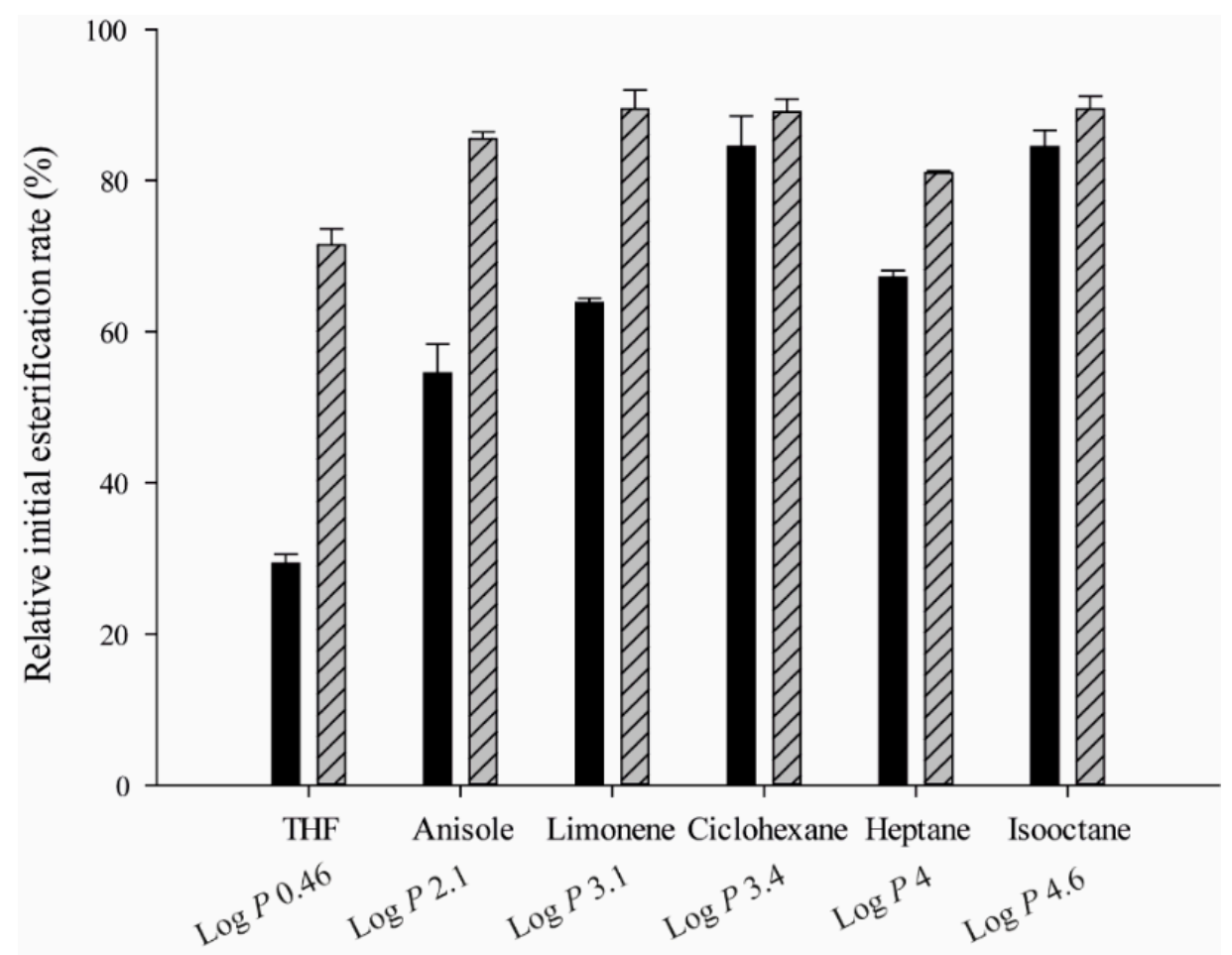

Figure 2. Relative initial reaction rate (\%) of ethyl butyrate synthesis after incubation of the biocatalysts for $24 \mathrm{~h}$ in the following solvents: tetrahydrofuran (THF), anisole, limonene, cyclohexane, heptane and isooctane. The Log $p$ values for each solvent are shown under its name. EB-rROL (black). EB-proROL (striped grey). The initial reaction rate for each non-incubated biocatalyst was taken to be $100 \%$.

The presence of the truncated prosequence had a positive effect on EB-proROL stability, which exceeded that of EB-rROL in all cases. In fact, EB-proROL was 2.5 times more stable than EB-rROL in tetrahydrofuran (THF), the most extreme case. In anisole and limonene, two solvents with a high potential for use in green chemistry [42] and medium Log $p$ values, EB-proROL was about 30\% more stable than EB-rROL. Log $p$ had a marked effect on biocatalyst stability, decreasing values - thus, more miscible solvents with water, such as THF-leading to increasing reduction of stability due to the removal of structural water from the enzymes, which is required to maintain their 3D structure and activity [43]. Obviously, the adverse effects of $\operatorname{low} \log p$ values on proROL were less marked than those on rROL. 
The results for EB-rROL in heptane and isooctane were compared with previously reported values for rROL immobilized onto various supports (EP100, Eupergit ${ }^{\circledR}$ CM and octadecyl-Sepabeads). This way, immobilization onto the EB support obtained from Purolite ${ }^{\circledR}$ was found to increase the stability of rROL [44].

\subsection{Transesterification and Esterification Reactions. Initial Reaction Rate and Operational Stability}

rROL and proROL free lipases were covalently immobilized onto a Purolite ${ }^{\circledR}$ D6307 support containing epoxide and butyl functional groups (EB) to elucidate the influence of the 28 amino acids in the lipase on the initial reaction rate and operational stability of the biocatalyst during biodiesel and ethyl butyrate production.

\subsubsection{Biodiesel Production}

The enzymatic production of biodiesel has several advantages in terms of process sustainability over its chemical production. However, only exceptionally stable biocatalysts allow cost-effective production $[45,46]$. This led us to assess the potential of the truncated prosequence of ROL for increasing the operational stability of the resulting biocatalyst under enzymatic biodiesel production conditions and its influence on the initial transesterification rate. In addition, due to 1,3-regiospecificity of Rhizopus oryzae lipase, the stoichiometric amount of alcohol (viz., a 2:1 alcohol-to-oil mole ratio) was employed to avoid the presence of too high alcohol concentration in reaction medium and hence, further adverse effects on the operational stability. Besides, ROL regioespecificity avoids glycerol formation during transesterification-a low value compound that might hinder enzyme performance [47] — and gives 2-monoacylglyceride a product with a high added value for the cosmetics and food industries [48].

No differences in initial reaction rate were observed between the two biocatalysts studied: EB-rROL and EB-proROL (Table 4). Therefore, the presence of the 28 amino acids in proROL had no influence on this parameter even though previous results suggested that its being close to the "lid region" in the 3D structure might interfere with interfacial activation and substrate-enzyme interaction processes [49,50].

Table 4. EB-rROL and EB-proROL initial transesterification and esterification rates, productivity and half-lives as calculated by using the best-fitting deactivation model.

\begin{tabular}{ccccc}
\hline \multirow{2}{*}{ Reaction } & Biocatalyst & $\begin{array}{c}\text { Initial Rate } \\
(\mu \mathbf{m o l} \text { Product } \\
\left.\mathbf{m L}^{-\mathbf{1}} \mathbf{m i n}^{-\mathbf{1}}\right)\end{array}$ & $\begin{array}{c}\text { Productivity } \\
(\mu \mathbf{m o l} \text { Product } \\
\left.\mathbf{m i n}^{-1}\right)\end{array}$ & Half-Life (h) \\
\hline \multirow{2}{*}{ Transesterification } & EB-proROL & 27.2 & 39.43 & 498 \\
\cline { 2 - 5 } & EB-rROL & 25.1 & 34.17 & 102 \\
\hline \multirow{2}{*}{ Esterification } & EB-proROL & 308 & 4.74 & 70 \\
\cline { 2 - 5 } & EB-rROL & 294 & 3.10 & 30 \\
\hline
\end{tabular}

As regards operational stability, Figure 3A shows the relative yield obtained in consecutive transesterification reaction cycles with each immobilized lipase. After 8 cycles, EB-proROL exhibited the greatest operational stability, with a relative yield exceeding $90 \%$ of the initial value and that of EB-rROL $(70 \%)$ by $25 \%$. These results testify to the influence of biocatalyst stability on productivity and half-life (Table 4). In fact, after 8 reaction cycles EB-proROL exhibited 15\% higher productivity than EB-rROL. Half-lives were calculated by fitting the experimental relative yields with the deactivation models described in Section 3.8. The results obtained with EB-proROL fitted Equation (2) (Equation (2), a two-component first-order exponential decay model (2)) more closely than they fitted Equation (1) (Equation (1), a first-order exponential decay model (1)); thus, $R^{2}$ was 0.844 with Equation (2) and 0.7389 with Equation (1). On the other hand, the results for EB-rROL fitted both models almost identically well, $R^{2}$ being 0.977 with Equation (1) 
and 0.991 with Equation (2). The best model for each biocatalyst (Equation (2)) was used to calculate the corresponding half-life. As can be seen from Table $4, t_{1 / 2}$ was almost 5 times greater with EB-proROL than it was with EB-rROL. Similar results were previously obtained with a whole-cell ROL biocatalyst (456 h) [51], rROL immobilized onto Purolite ${ }^{\circledR}$ Lifetech $^{\mathrm{TM}}$ ECR1030M (579 h) and IRA-96 (381 h) [52]. By contrast, rROL immobilized onto AP1090M and Lewatit VP OC 1600 had a markedly shorter half-life (270 and $113 \mathrm{~h}$, respectively). Interestingly, $\mathrm{rROL}$ immobilized onto Lifetech ${ }^{\mathrm{TM}} \mathrm{ECR} 8285 \mathrm{M}-\mathrm{a}$ biocatalyst identical with EB-rROL — had a much shorter half-life: $16 \mathrm{~h}$ [52]. Since the only difference was that in reaction conditions, these results testify to the importance of reaction conditions in biocatalyst operational stability.
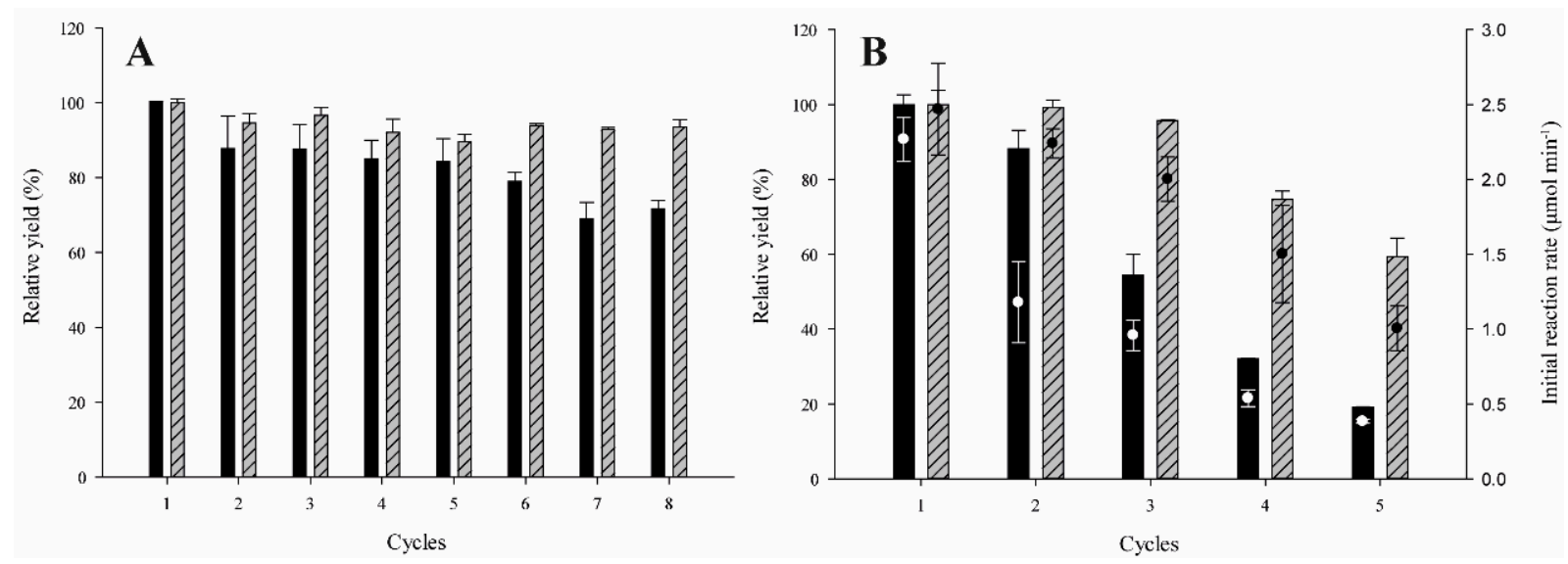

Figure 3. (A) Relative yield of consecutive transesterification runs with each biocatalyst as obtained by following the 1-pulse ethanol addition procedure. (B) Relative yield of consecutive esterification reactions of each biocatalyst as obtained with butyric acid and ethanol as substrates. EB-rROL (black) and EB-proROL (striped grey). The final yield of the first run was taken to be $100 \%$.

\subsubsection{Ethyl Butyrate Production}

Short-chain esters are arousing increasing interest in sectors such as agri-food and cosmetic production by virtue of their pleasant sensory attributes [53]. One such ester is ethyl butyrate, which possesses a characteristic strong pineapple flavor and can be obtained by esterifying butyric acid with ethanol. Although ROL has been successfully used to synthesize ethyl butyrate, previous work showed that a more stable lipase is needed to prevent deactivation by both the acid and the alcohol [54]. This led us to test immobilized proROL here for comparison with rROL in order to assess the significance of the truncated prosequence with a view to improving the operational stability of the biocatalyst in this bioprocess and examining its influence on the initial reaction rate.

As in biodiesel production, the truncated prosequence had no effect on the initial esterification rate. In fact, both biocatalysts led to an identical value in the first reaction cycle (Table 4, Figure 3B). On the other hand, the truncated prosequence strongly affected the operational stability of the biocatalyst during ethyl butyrate synthesis-even to a greater extent than in biodiesel production. Thus, after 5 reaction cycles, EB-proROL led to a 3 times higher relative yield than did EB-rROL (Figure 3B). As a result, productivity with EB-proROL was 35\% higher than it was with EB-rROL. The half-lives of the two biocatalysts were calculated by fitting the relative yield results to Equations (1) and (2). Both fitted Equation (2) better than they fitted Equation (1) (EB-rROL $R^{2}=0.9004$ and EB-proROL $\left.R^{2}=0.9694\right)$. Besides, EB-proROL proved more stable (Table 4): its half-life was 2.5 times greater. Therefore, EB-proROL stands as a promising biocatalyst to avoid deactivation by ethanol or butyric acid during esterification. 


\section{Materials and Methods}

\subsection{Chemicals}

Olive pomace oil (alperujo) was a gift from Professor Eulogio Castro (University of Jaen, Spain). The immobilization support (polymethacrylate-based matrix D6307 containing epoxy and butyl functional groups) was kindly donated by Purolite ${ }^{\circledR}$ (King of Prussia, PA, USA). Heptane, methanol and ethanol were purchased from Panreac (Barcelona, Spain). Butyric acid, ethyl butyrate, standards of methyl/ethyl palmitate, methyl/ethyl stearate, methyl/ethyl oleate, methyl/ethyl linoleate, methyl linoleate and all other reagents were obtained from Sigma-Aldrich (St. Louis, MO, USA).

\subsection{Strains and Plasmids}

Four different plasmids were used, namely: two $\mathrm{PPICZ} \alpha \mathrm{A}$ plasmids containing the mature sequence of Rhizopus oryzae lipase (rROL $\mathrm{P}_{A O X 1}$-plasmid), and a derivative thereof containing the $28 \mathrm{C}$-terminal amino acids of the prosequence of the native lipase in the $\mathrm{N}$-terminal of $\mathrm{rROL}$ (proROL $\mathrm{P}_{A O X 1}$-plasmid), the pair expressed under the inducible promoter of alcohol oxidase $1\left(\mathrm{P}_{A O X 1}\right)$ [7]. In both plasmids, $\mathrm{P}_{A O X 1}$ was replaced with the constitutive glyceraldehyde-3-phosphate dehydrogenase promoter $\left(\mathrm{P}_{G A P}\right)$ from pGAPZ $\alpha \mathrm{A}$ plasmid. Because exchanged fragments natively contained flanking sequences of BgIII and XhoI restrictions sites, no unwanted nucleotides remained in the anew formed plasmids (rROL $\mathrm{P}_{G A P}$-plasmid and proROL $\mathrm{P}_{G A P}$-plasmid). More detailed information about the plasmids is provided in the Supplementary Material.

Pichia pastoris X33 strains were transformed by electroporing $100 \mathrm{ng}$ of previously linearized proROL $\mathrm{P}_{\mathrm{GAP}}$-plasmid and $\mathrm{rROL} \mathrm{P}_{\mathrm{GAP}}$-plasmid. A blank consisting of empty pPICZ $\alpha \mathrm{A}$ plasmid with the promoter exchanged was additionally used as a control. The resulting colonies were re-streaked twice on YPD-Zeo plates to avoid population mixing, and five isolated colonies screened as described elsewhere [55], the most representative colony in each run being selected for further study. Single-gene copies were confirmed by digital droplet PCR [56].

\subsection{Batch Cultures}

An inoculum containing $100 \mathrm{~mL}$ of YPG medium plus zeocin to a final concentration of $100 \mu \mathrm{g} \mathrm{mL} \mathrm{m}^{-1}$ was grown in a $1 \mathrm{~L}$ baffled shake flask at $30{ }^{\circ} \mathrm{C}$ that was stirred at $150 \mathrm{rpm}$ for $24 \mathrm{~h}$ [57]. Then, a sample was centrifuged and resuspended in $100 \mathrm{~mL}$ of sterile water to inoculate the bioreactor to a final optical density $\left(\mathrm{OD}_{600}\right)$ in $1 \mathrm{~L}$ of culture medium containing glycerol as sole carbon source [57]. Batch cultures were run in a $2 \mathrm{~L}$ bioreactor from Applikon Biotechnology (Delft, The Netherlands). The growing conditions were adapted from reported recommendations [58]. Thus, the temperature was kept at $30{ }^{\circ} \mathrm{C}$, and $\mathrm{pH} 5$ was maintained by adding $15 \%(v / v) \mathrm{NH}_{4} \mathrm{OH}$ as required. The oxygen concentration was set at $25 \%$ and controlled by cascade stirring at 500-1200 rpm with constant aeration at $1 \mathrm{vvm}$.

The end of each batch run was detected as an abrupt increase in dissolved oxygen (DO) concentration [58]. All tests were performed in duplicate.

\subsection{Fed-Batch Cultures}

The inoculum was grown as described in the previous section and added to the bioreactor at a final $\mathrm{OD}_{600}$ of $1.5 \mathrm{in} 2 \mathrm{~L}$ of the same culture medium used in the batch tests. Fedbatch cultures were run in a 5 L Biostat B bioreactor from Sartorius (Guxhagen, Germany).

Batch and fed-batch stages were run by following previously reported procedures that were modified as described in the previous section [58]. The fed-batch stage was conducted with glucose as sole carbon source, using a carbon-limited feeding strategy and a preset exponential feeding rate intended to maintain a constant specific growth rate of $0.045 \mathrm{~h}^{-1}$.

All equations used to calculate yields and rates are based on mass balances in batch and fed-batch operations, and can be found elsewhere [59]. 


\subsection{Lipase Production and Activity Assessment}

Fed-batch bioprocesses were followed by centrifugation, microfiltration, ultrafiltration and lyophilization of the culture broth to remove biomass in order to concentrate rROL and proROL [60]. Due to the impossibility of producing rROL under the constitutive promoter $\left(\mathrm{P}_{G A P}\right)$, the mature sequence lipase rROL was obtained from Komagataella phaffii strains producing the protein under the methanol inducible promoter $\left(\mathrm{P}_{A O X 1}\right)$ [7].

proROL derived lipase (proROLm) was obtained by action of proteases [7]. Then, centrifugation and passage through $0.2 \mu \mathrm{m}$ filters was performed to remove unwanted contaminants.

Lipase activity was determined on a Cary 300 spectrophotometer from Varian (Mulgrave, VIC, Australia), using the 11821792 lipase colorimetric kit from Roche (Mannheim, Germany) in $200 \mathrm{mM}$ Tris- $\mathrm{HCl}$ buffer at $\mathrm{pH} 7.25$ at $30^{\circ} \mathrm{C}$. Measurements were made in triplicate at $580 \mathrm{~nm}$ [61].

\subsection{N-Terminal Analysis}

The N-terminal sequences of proROL, proROLm and rROL were determined by automated Edman's degradation as described elsewhere [62]. The resulting sequences were further examined by using the Protein BLAST tool from the National Centre for Biotechnology Information (NCBI).

\subsection{Lipase Immobilization}

proROL and rROL were immobilized onto a pretreated polymethacrylate matrix support (Purolite ${ }^{\circledR}$ D6307 with epoxide and butyl functional groups) by following a slightly modified version of a previously reported procedure [63]. Thus, epoxide functional groups were pretreated by incubating $1 \mathrm{~g}$ of support with $1 \mathrm{M}$ ethylenediamine solution $\mathrm{pH} 10$ under orbital stirring during $4 \mathrm{~h}$ at $60^{\circ} \mathrm{C}$. Then, rinsed with distilled water by vacuum filtration and incubated in a $2.5 \% w / v$ glutaraldehyde solution at $\mathrm{pH} 8$ on a roller during $2 \mathrm{~h}$ at room temperature. Finally, after rinsing the support, glutaraldehyde-treated support was incubated with a $600 \mathrm{AU} \mathrm{mL} \mathrm{L}^{-1}$ lipase solution at $4{ }^{\circ} \mathrm{C}$ for $42 \mathrm{~h}$. The biocatalysts thus obtained (EB-rROL and EB-proROL) were vacuum-filtered, dried on silica gel and stored at $-20^{\circ} \mathrm{C}$ until use.

The specific activity of the immobilized derivative was calculated by dividing the difference between final blank and final supernatant activity into the final dry weight of biocatalyst.

\subsection{Transesterification and Esterification Reactions}

All transesterification and esterification reactions were conducted in $10 \mathrm{~mL}$ closed vials that were placed in a KS 400 incubator from IKA Werke (Staufen, Germany) at $30^{\circ} \mathrm{C}$ under orbital stirring at $350 \mathrm{rpm}$. Samples were periodically taken for reaction performance assessment by gas chromatography.

Biodiesel transesterification reactions were run by using a total amount of biocatalyst corresponding to $32,000 \mathrm{AU}$ and $8 \mathrm{~g}$ of olive pomace oil for $6 \mathrm{~h}$. The stoichiometric amount of alcohol (2:1 alcohol to oil mole ratio) needed to obtain the theoretical maximum yield ( $66 \%$ based on the 1,3-regiospecificity of ROL) was added at the beginning of the reaction by following the already described 1-pulse ethanol addition procedure [64]. Operational stability was measured by allowing the biocatalysts to settle in the vial bottom and removing the medium after each reaction run. Then, all reaction components were prepared for subsequent transesterification cycles [64].

The initial transesterification rate was determined by using a previously reported method [63]. Briefly, $1.56 \%(w / w)$ of methanol was added to olive pomace oil-the stoichiometric amount needed to obtain a yield of ca. $14 \%$ - and samples were withdrawn for analysis at regular intervals over the first $90 \mathrm{~min}$ of reaction.

Ethyl butyrate production reactions were conducted by using $100 \mathrm{mM}$ butyric acid and an acid:alcohol mole ratio of 1.25:1 to a final heptane volume of $8 \mathrm{~mL}$. All substrates and solvents were dried with UOP type 3 molecular sieves from Sigma Aldrich (St. Louis, 
MO, USA) prior to use. The biocatalysts were also dried, albeit by placing the amounts corresponding to $10,000 \mathrm{AU}$ in a dryer containing silica gel. Operational stability tests were performed by removing used reaction medium and rinsing the biocatalysts with heptane twice. Then, immobilized derivatives were allowed to stand in the dryer for $24 \mathrm{~h}$ before the next reaction run [44]. Initial esterification rates were determined by withdrawing samples regularly over the first 90 min of reaction.

The relative yields of consecutive transesterification and esterification cycles as calculated relative to the final yield of the first reaction cycle were fitted by using a first-order exponential decay model (1) and two-component first-order exponential decay model (2):

$$
\begin{gathered}
\mathrm{Y}(\%)_{\mathrm{t}}=100 e^{-k \mathrm{t}}, \\
\mathrm{Y}(\%)_{\mathrm{t}}=100 e^{-k_{1}{ }^{\mathrm{t}}+\mathrm{c} e^{-k_{2} \mathrm{t}}}
\end{gathered}
$$

where $k, k_{1}$ and $k_{2}$ are deactivation coefficients. All computations were done with the software Sigma Plot v. 14 [52,65].

\subsection{Gas Chromatography}

Fatty acid methyl and ethyl esters (FAME and FAEE, respectively), and ethyl butyrate concentrations formed in the transesterification and esterification reactions, were determined on a 7890A gas chromatograph from Agilent (Santa Clara, CA, USA) equipped with a $19095 \mathrm{~N}-123$ capillary column and an autosampler $[44,66]$. The relative standard deviations (RSD) never exceeded 3\%.

\subsection{Immobilized Lipase Stability against Organic Solvents}

The stability of EB-proROL and EB-rROL against organic solvents was assessed by using closed vials of $10 \mathrm{~mL}$. Thus, a total amount of $5000 \mathrm{AU}$ of each biocatalyst was incubated with $5 \mathrm{~mL}$ of the corresponding solvent at $25^{\circ} \mathrm{C}$ under stirring at $350 \mathrm{rpm}$ in the IKA KS 400 incubator for $24 \mathrm{~h}$. Then, the biocatalysts were washed with heptane twice and the initial rate of ethyl butyrate production was determined as described in Section 3.8. All data given are relative to the initial reaction rate of the same amount of non-incubated biocatalyst for each lipase.

\section{Conclusions}

The truncated prosequence of Rhizopus oryzae lipase was confirmed to suffice in order to alleviate the adverse effects on proROL and enable its expression in K. phaffii under the constitutive promoter $\mathrm{P}_{G A P}$ with glucose and glycerol as substrates and hence to avoid the need for methanol. A more environmentally friendly bioprocess for proROL production afforded final activity and productivity values similar to those obtained with the best existing methanol feeding strategy. Preferential hydrolysis of the 28 amino acids in the truncated prosequence was demonstrated by $\mathrm{N}$-terminal analysis (that is, the 28 amino acids were confirmed to be naturally designed for removal). In addition, the truncated prosequence increased the tolerance of organic solvents, and the operational stability in biodiesel and ethyl butyrate production, of EB-proROL relative to EB-rROL. However, no influence on initial reaction rates was observed, which suggests that EB-proROL and EB-rROL interact identically with the substrates under the studied conditions.

Supplementary Materials: The following are available online at https:/ /www.mdpi.com/article/ 10.3390/catal11101192/s1, Figure S1: rROL $\mathrm{P}_{A O X 1}$-plasmid: plasmid containing the sequence of rROL under $\mathrm{P}_{A O X 1}$. Figure S2: proROL $\mathrm{P}_{A O X 1}$-plasmid: plasmid containing the sequence of proROL under $\mathrm{P}_{A O X 1}$. Figure S3: rROL $\mathrm{P}_{G A P}$-plasmid: plasmid containing the sequence of rROL under $\mathrm{P}_{G A P}$. Figure S4: proROL $\mathrm{P}_{G A P}$-plasmid: plasmid containing the sequence of proROL under $\mathrm{P}_{G A P}$.

Author Contributions: Conceptualization, J.L.-F., M.D.B. and F.V.; methodology, J.L.-F.; validation, J.L.-F., M.D.B. and F.V.; formal analysis, J.L.-F.; investigation, J.L.-F.; resources, M.D.B. and F.V.; data curation, J.L.-F.; writing-original draft preparation, J.L.-F.; writing—review and editing, M.D.B. 
and F.V.; visualization, J.L.-F.; supervision, M.D.B. and F.V.; project administration, M.D.B. and F.V.; funding acquisition, F.V. All authors have read and agreed to the published version of the manuscript.

Funding: This work was funded by the Spanish Ministry of Science and Innovation (Project PID2019104666GB-100).

Acknowledgments: JLF was supported by a Basque Government scholarship for the training of pre-doctoral researchers (PRE_2017_1_0110).

Conflicts of Interest: The authors declare no conflict of interest.

\author{
Abbreviations \\ ROL \\ rROL \\ proROL \\ proROLm \\ rROL-gene \\ proROL-gene \\ EB \\ EB-rROL \\ EB-proROL \\ rROL P $P_{A O X 1}$-plasmid \\ proROL $\mathrm{P}_{A O X 1}$-plasmid \\ rROL $P_{G A P}$-plasmid \\ proROL $P_{G A P}$-plasmid \\ rROL $\mathrm{P}_{A O X 1^{-} \text {-strain }}$ \\ proROL $\mathrm{P}_{A O X 1 \text {-strain }}$ \\ rROL $P_{G A P}$-strain \\ proROL $\mathrm{P}_{G A P^{-s t r a i n}}$ \\ MNLFB \\ MLFB \\ $\mathrm{Y}_{(\mathrm{P} / \mathrm{X})}$ \\ $\mu$ \\ $q_{\mathrm{p}}$
}

Specific productivity (AU gX ${ }^{-1} \mathrm{~h}^{-1}$ )

Volumetric productivity (AU $\mathrm{L}^{-1} \mathrm{~h}^{-1}$ )

$\mathrm{P}_{\text {AOX1 }}$

$\mathrm{P}_{G A P}$
Rhizopus oryzae lipase.

Recombinant Rhizopus oryzae lipase formed by the mature sequence.

Lipase formed by the C-terminal 28 amino acids of the native prosequence of ROL fused to the $\mathrm{N}$-terminal in the mature sequence.

proROL modified by the activity of proteases.

w-proROL-gene: Gene encoding the whole prosequece fused to the mature sequence of Rhizopus oryzae lipase. Gene encoding the mature sequence of Rhizopus oryzae lipase.

Gene encoding the C-terminal 28 amino acids of the native prosequence of ROL fused to the $\mathrm{N}$-terminal of the mature sequence.

Purolite ${ }^{\circledR}$ polymethacrylate matrix support with butyl and epoxide surface groups

rROL covalently immobilized onto the EB support. proROL covalently immobilized onto the EB support. Plasmid containing the mature sequence of Rhizopus oryzae lipase under $\mathrm{P}_{A O X 1}$.

Plasmid containing the sequence of proROL under $\mathrm{P}_{A O X 1}$. Plasmid containing the mature sequence of

Rhizopus oryzae lipase under $\mathrm{P}_{G A P}$.

Plasmid containing the proROL sequence under $\mathrm{P}_{G A P}$. Genetically modified Komagataella phaffii strain used to produce rROL under $\mathrm{P}_{A O X 1}$.

Genetically modified Komagataella phaffii strain used to produce proROL under $\mathrm{P}_{A O X 1}$.

Genetically modified Komagataella phaffii strain used to produce rROL under $\mathrm{P}_{G A P}$.

Genetically modified Komagataella phaffii strain used to produce proROL under $\mathrm{P}_{G A P}$.

Methanol non-limited fed-batch.

Methanol limited fed-batch.

Product biomass yield (AU gX $\left.{ }^{-1}\right)$.

Specific growth rate $\left(\mathrm{h}^{-1}\right)$.

Specific production rate $\left(\mathrm{AU} \mathrm{gX}^{-1} \mathrm{~h}^{-1}\right)$ : parameter which shows an average of all the analyzed points during the bioprocess.

Parameter of the entire bioprocess, analyzed at the end of it.

Parameter of the entire bioprocess, analyzed at the end of it.

Inducible alcohol oxidase 1 promoter.

Constitutive glyceraldehyde-3-phosphate dehydrogenase 


\section{References}

1. Bornscheuer, U.T. The fourth wave of biocatalysis is approaching. Philos. Trans. R. Soc. A Math. Phys. Eng. Sci. 2018, $376,20170063$. [CrossRef] [PubMed]

2. Bilal, M.; Iqbal, H.M.N. Armoring bio-catalysis via structural and functional coordination between nanostructured materials and lipases for tailored applications. Int. J. Biol. Macromol. 2021, 166, 818-838. [CrossRef] [PubMed]

3. Todo Bom, M.A.; Botton, V.; Altheia, F.M.; Thomas, J.C.; Piovan, L.; Córdova, J.; Mitchell, D.A.; Krieger, N. Fermented solids that contain lipases produced by Rhizopus microsporus have an S-enantiopreference in the resolution of secondary alcohols. Biochem. Eng. J. 2021, 165, 107817. [CrossRef]

4. Ismail, A.R.; Kashtoh, H.; Baek, K.H. Temperature-resistant and solvent-tolerant lipases as industrial biocatalysts: Biotechnological approaches and applications. Int. J. Biol. Macromol. 2021, 187, 127-142. [CrossRef]

5. López-Fernández, J.; Benaiges, M.D.; Valero, F. Rhizopus oryzae lipase, a promising industrial enzyme: Biochemical characteristics, production and biocatalytic applications. Catalysts 2020, 10, 1277. [CrossRef]

6. Salah, R.B.; Mosbah, H.; Fendri, A.; Gargouri, A.; Gargouri, Y.; Mejdoub, H. Biochemical and molecular characterization of a lipase produced by Rhizopus oryzae. FEMS Microbiol. Lett. 2006, 260, 241-248. [CrossRef]

7. López-Fernández, J.; Barrero, J.J.; Benaiges, M.D.; Valero, F. Truncated prosequence of Rhizopus oryzae lipase: Key factor for production improvement and biocatalyst stability. Catalysts 2019, 9, 961. [CrossRef]

8. Resina, D.; Maurer, M.; Cos, O.; Arnau, C.; Carnicer, M.; Marx, H.; Gasser, B.; Valero, F.; Mattanovich, D.; Ferrer, P. Engineering of bottlenecks in Rhizopus oryzae lipase production in Pichia pastoris using the nitrogen source-regulated FLD1 promoter. New Biotechnol. 2009, 25, 396-403. [CrossRef]

9. Satomura, A.; Kuroda, K.; Ueda, M. Generation of a functionally distinct Rhizopus oryzae lipase through protein folding memory. PLoS ONE 2015, 10, e0124545. [CrossRef]

10. Beer, H.D.; Wohlfahrt, G.; Schmid, R.D.; McCarthy, J.E. The folding and activity of the extracellular lipase of Rhizopus oryzae are modulated by a prosequence. Biochem. J. 1996, 319, 351-359. [CrossRef]

11. Shinde, U.; Inouye, M. Intramolecular chaperones: Polypeptide extensions that modulate protein folding. Semin. Cell Dev. Biol. 2000, 11, 35-44. [CrossRef]

12. Chapman, J.; Ismail, A.E.; Dinu, C.Z. Industrial applications of enzymes: Recent advances, techniques, and outlooks. Catalysts 2018, 8, 238. [CrossRef]

13. Bilal, M.; Cui, J.; Iqbal, H.M.N. Tailoring enzyme microenvironment: State-of-the-art strategy to fulfill the quest for efficient bio-catalysis. Int. J. Biol. Macromol. 2019, 130, 186-196. [CrossRef]

14. Bilal, M.; Iqbal, H.M.N.; Guo, S.; Hu, H.; Wang, W.; Zhang, X. State-of-the-art protein engineering approaches using biological macromolecules: A review from immobilization to implementation view point. Int. J. Biol. Macromol. 2018, 108, 893-901. [CrossRef]

15. Ismail, A.R.; Baek, K.H. Lipase immobilization with support materials, preparation techniques, and applications: Present and future aspects. Int. J. Biol. Macromol. 2020, 163, 1624-1639. [CrossRef]

16. Bonet-Ragel, K.; López-Pou, L.; Tutusaus, G.; Benaiges, M.D.; Valero, F. Rice husk ash as a potential carrier for the immobilization of lipases applied in the enzymatic production of biodiesel. Biocatal. Biotransform. 2018, 36, 151-158. [CrossRef]

17. Pashangeh, K.; Akhond, M.; Karbalaei-Heidari, H.R.; Absalan, G. Biochemical characterization and stability assessment of Rhizopus oryzae lipase covalently immobilized on amino-functionalized magnetic nanoparticles. Int. J. Biol. Macromol. 2017, 105, 300-307. [CrossRef]

18. Ghattas, N.; Abidi, F.; Galai, S.; Marzouki, M.N.; Salah, A. Ben Monoolein production by triglycerides hydrolysis using immobilized Rhizopus oryzae lipase. Int. J. Biol. Macromol. 2014, 68, 1-6. [CrossRef]

19. Kartal, F.; Kilinc, A. Crosslinked aggregates of Rhizopus oryzae lipase as industrial biocatalysts: Preparation, optimization, characterization, and application for enantioselective resolution reactions. Biotechnol. Prog. 2012, 28, 937-945. [CrossRef]

20. Yu, X.W.; Xu, Y.; Xiao, R. Lipases from the genus Rhizopus: Characteristics, expression, protein engineering and application. Prog. Lipid Res. 2016, 64, 57-68. [CrossRef]

21. Beer, H.D.; McCarthy, J.E.G.; Bornscheuer, U.T.; Schmid, R.D. Cloning, expression, characterization and role of the leader sequence of a lipase from Rhizopus oryzae. Biochim. Biophys. Acta-Gene Struct. Expr. 1998, 1399, 173-180. [CrossRef]

22. Di Lorenzo, M.; Hidalgo, A.; Haas, M.; Bornscheuer, U.T. Heterologous production of functional forms of Rhizopus oryzae lipase in Escherichia coli. Appl. Environ. Microbiol. 2005, 71, 8974-8977. [CrossRef] [PubMed]

23. Niu, W.; Li, Z.; Tan, T. Secretion of pro- and mature Rhizopus arrhizus lipases by Pichia pastoris and properties of the proteins. Mol. Biotechnol. 2006, 32, 73-81. [CrossRef]

24. Minning, S.; Schmidt-Dannert, C.; Schmid, R.D. Functional expression of Rhizopus oryzae lipase in Pichia pastoris: High-level production and some properties. J. Biotechnol. 1998, 66, 147-156. [CrossRef]

25. Chahed, H.; Boumaiza, M.; Ezzine, A.; Marzouki, M.N. Heterologous expression and biochemical characterization of a novel thermostable Sclerotinia sclerotiorum GH45 endoglucanase in Pichia pastoris. Int. J. Biol. Macromol. 2018, 106, 629-635. [CrossRef]

26. Sturmberger, L.; Chappell, T.; Geier, M.; Krainer, F.; Day, K.J.; Vide, U.; Trstenjak, S.; Schiefer, A.; Richardson, T.; Soriaga, L.; et al. Refined Pichia pastoris reference genome sequence. J. Biotechnol. 2016, 235, 121-131. [CrossRef] 
27. Garrigós-Martínez, J.; Nieto-Taype, M.A.; Gasset-Franch, A.; Montesinos-Seguí, J.L.; Garcia-Ortega, X.; Valero, F. Specific growth rate governs AOX1 gene expression, affecting the production kinetics of Pichia pastoris (Komagataella phaffii) $\mathrm{P}_{A O X 1}$-driven recombinant producer strains with different target gene dosage. Microb. Cell Fact. 2019, 18, 187. [CrossRef]

28. Garrigós-Martínez, J.; Vuoristo, K.; Nieto-Taype, M.A.; Tähtiharju, J.; Uusitalo, J.; Tukiainen, P.; Schmid, C.; Tolstorukov, I.; Madden, K.; Penttilä, M.; et al. Bioprocess performance analysis of novel methanol-independent promoters for recombinant protein production with Pichia pastoris. Microb. Cell Fact. 2021, 20, 74. [CrossRef]

29. García-Ortega, X.; Cámara, E.; Ferrer, P.; Albiol, J.; Montesinos-Seguí, J.L.; Valero, F. Rational development of bioprocess engineering strategies for recombinant protein production in Pichia pastoris (Komagataella phaffii) using the methanol-free GAP promoter. Where do we stand? New Biotechnol. 2019, 53, 24-34. [CrossRef]

30. Müller, J.M.; Bruhn, S.; Flaschel, E.; Friehs, K.; Risse, J.M. GAP promoter-based fed-batch production of highly bioactive core streptavidin by Pichia pastoris. Biotechnol. Prog. 2016, 32, 855-864. [CrossRef]

31. Nieto-Taype, M.A.; Garrigós-Martínez, J.; Sánchez-Farrando, M.; Valero, F.; Garcia-Ortega, X.; Montesinos-Seguí, J.L. Rationalebased selection of optimal operating strategies and gene dosage impact on recombinant protein production in Komagataella phaffii (Pichia pastoris). Microb. Biotechnol. 2020, 13, 315-327. [CrossRef]

32. Yu, X.W.; Yang, M.; Jiang, C.; Zhang, X.; Xu, Y. N-Glycosylation engineering to improve the constitutive expression of Rhizopus oryzae lipase in Komagataella phaffii. J. Agric. Food Chem. 2017, 65, 6009-6015. [CrossRef]

33. Ponte, X.; Barrigón, J.M.; Maurer, M.; Mattanovich, D.; Valero, F.; Montesinos-Seguí, J.L. Towards optimal substrate feeding for heterologous protein production in Pichia pastoris (Komagataella spp.) fed-batch processes under $\mathrm{P}_{\text {AOX1 }}$ control: A modeling aided approach. J. Chem. Technol. Biotechnol. 2018, 93, 3208-3218. [CrossRef]

34. Kluge, J.; Terfehr, D.; Kück, U. Inducible promoters and functional genomic approaches for the genetic engineering of filamentous fungi. Appl. Microbiol. Biotechnol. 2018, 102, 6357-6372. [CrossRef]

35. Hama, S.; Tamalampudi, S.; Shindo, N.; Numata, T.; Yamaji, H.; Fukuda, H.; Kondo, A. Role of N-terminal 28 amino acid region of Rhizopus oryzae lipase in directing proteins to secretory pathway of Aspergillus oryzae. Appl. Microbiol. Biotechnol. 2008, 79, 1009-1018. [CrossRef]

36. Barrigón, J.M.; Montesinos, J.L.; Valero, F. Searching the best operational strategies for Rhizopus oryzae lipase production in Pichia pastoris $\mathrm{Mut}^{+}$phenotype: Methanol limited or methanol non-limited fed-batch cultures? Biochem. Eng. J. 2013, 75, 47-54. [CrossRef]

37. Kohno, M.; Kugimiya, W.; Hashimoto, Y.; Morita, Y. Purification, characterization, and crystallization of two types of lipase from Rhizopus niveus. Biosci. Biotechnol. Biochem. 1994, 58, 1007-1012. [CrossRef]

38. Guillén, M.; Benaiges, M.D.; Valero, F. Comparison of the biochemical properties of a recombinant lipase extract from Rhizopus oryzae expressed in Pichia pastoris with a native extract. Biochem. Eng. J. 2011, 54, 117-123. [CrossRef]

39. Takahashi, S.; Ueda, M.; Tanaka, A. Independent production of two molecular forms of a recombinant Rhizopus oryzae lipase by KEX2-engineered strains of Saccharomyces cerevisiae. Appl. Microbiol. Biotechnol. 1999, 52, 534-540. [CrossRef]

40. Kumar, A.; Dhar, K.; Kanwar, S.S.; Arora, P.K. Lipase catalysis in organic solvents: Advantages and applications. Biol. Proced. Online 2016, 18, 2. [CrossRef]

41. Hiol, A.; Jonzo, M.D.; Rugani, N.; Druet, D.; Sarda, L.; Comeau, L.C. Purification and characterization of an extracellular lipase from a thermophilic Rhizopus oryzae strain isolated from palm fruit. Enzym. Microb. Technol. 2000, 26, 421-430. [CrossRef]

42. McDowell, C.; Bazan, G.C. Organic solar cells processed from green solvents. Curr. Opin. Green Sustain. Chem. 2017, 5, 49-54. [CrossRef]

43. Wang, S.; Meng, X.; Zhou, H.; Liu, Y.; Secundo, F.; Liu, Y. Enzyme stability and activity in non-aqueous reaction systems: A mini review. Catalysts 2016, 6, 32. [CrossRef]

44. Guillén, M.; Benaiges, M.D.; Valero, F. Biosynthesis of ethyl butyrate by immobilized recombinant Rhizopus oryzae lipase expressed in Pichia pastoris. Biochem. Eng. J. 2012, 65, 1-9. [CrossRef]

45. Zhong, L.; Feng, Y.; Wang, G.; Wang, Z.; Bilal, M.; Lv, H.; Jia, S.; Cui, J. Production and use of immobilized lipases in/on nanomaterials: A review from the waste to biodiesel production. Int. J. Biol. Macromol. 2020, 152, 207-222. [CrossRef]

46. López-Fernández, J.; Dolors Benaiges, M.; Valero, F. Second- and third-generation biodiesel production with immobilised recombinant Rhizopus oryzae lipase: Influence of the support, substrate acidity and bioprocess scale-up. Bioresour. Technol. 2021, 334, 125233. [CrossRef]

47. Rodrigues, A.; Bordado, J.C.; Dos Santos, R.G. Upgrading the glycerol from biodiesel production as a source of energy carriers and chemicals-A technological review for three chemical pathways. Energies 2017, 10, 1817. [CrossRef]

48. Luo, X.; Ge, X.; Cui, S.; Li, Y. Value-added processing of crude glycerol into chemicals and polymers. Bioresour. Technol. 2016, 215, 144-154. [CrossRef] [PubMed]

49. Sayari, A.; Frikha, F.; Miled, N.; Mtibaa, H.; Ali, Y.B.; Verger, R.; Gargouri, Y. N-terminal peptide of Rhizopus oryzae lipase is important for its catalytic properties. FEBS Lett. 2005, 579, 976-982. [CrossRef] [PubMed]

50. Cheng, C.; Jiang, T.; Wu, Y.; Cui, L.; Qin, S.; He, B. Elucidation of lid open and orientation of lipase activated in interfacial activation by amphiphilic environment. Int. J. Biol. Macromol. 2018, 119, 1211-1217. [CrossRef] [PubMed]

51. He, Q.; Shi, H.; Gu, H.; Naka, G.; Ding, H.; Li, X.; Zhang, Y.; Hu, B.; Wang, F. Immobilization of Rhizopus oryzae ly6 onto loofah sponge as a whole-cell biocatalyst for biodiesel production. BioResources 2016, 11, 850-860. [CrossRef] 
52. Rodrigues, J.; Canet, A.; Rivera, I.; Osório, N.M.; Sandoval, G.; Valero, F.; Ferreira-Dias, S. Biodiesel production from crude Jatropha oil catalyzed by non-commercial immobilized heterologous Rhizopus oryzae and Carica papaya lipases. Bioresour. Technol. 2016, 213, 88-95. [CrossRef]

53. Asmat, S.; Anwer, A.H.; Husain, Q. Immobilization of lipase onto novel constructed polydopamine grafted multiwalled carbon nanotube impregnated with magnetic cobalt and its application in synthesis of fruit flavours. Int. J. Biol. Macromol. 2019, 140, 484-495. [CrossRef]

54. Guillén, M.; Benaiges, M.D.; Valero, F. Improved ethyl butyrate synthesis catalyzed by an immobilized recombinant Rhizopus oryzae lipase: A comprehensive statistical study by production, reaction rate and yield analysis. J. Mol. Catal. B Enzym. 2016, 133, S371-S376. [CrossRef]

55. Barrero, J.J.; Casler, J.C.; Valero, F.; Ferrer, P.; Glick, B.S. An improved secretion signal enhances the secretion of model proteins from Pichia pastoris. Microb. Cell Fact. 2018, 17, 161-174. [CrossRef]

56. Cámara, E.; Albiol, J.; Ferrer, P. Droplet digital PCR-aided screening and characterization of Pichia pastoris multiple gene copy strains. Biotechnol. Bioeng. 2016, 113, 1542-1551. [CrossRef]

57. Maurer, M.; Kühleitner, M.; Gasser, B.; Mattanovich, D. Versatile modeling and optimization of fed batch processes for the production of secreted heterologous proteins with Pichia pastoris. Microb. Cell Fact. 2006, 5, 37-47. [CrossRef]

58. Garcia-Ortega, X.; Ferrer, P.; Montesinos, J.L.; Valero, F. Fed-batch operational strategies for recombinant Fab production with Pichia pastoris using the constitutive GAP promoter. Biochem. Eng. J. 2013, 79, 172-181. [CrossRef]

59. Ponte, X.; Montesinos-Seguí, J.L.; Valero, F. Bioprocess efficiency in Rhizopus oryzae lipase production by Pichia pastoris under the control of $\mathrm{P}_{A O X 1}$ is oxygen tension dependent. Process Biochem. 2016, 51, 1954-1963. [CrossRef]

60. Mendes, A.A.; Oliveira, P.C.; Vélez, A.M.; Giordano, R.C.; de LC Giordano, R.; de Castro, H.F. Evaluation of immobilized lipases on poly-hydroxybutyrate beads to catalyze biodiesel synthesis. Int. J. Biol. Macromol. 2012, 50, 503-511. [CrossRef]

61. Resina, D.; Serrano, A.; Valero, F.; Ferrer, P. Expression of a Rhizopus oryzae lipase in Pichia pastoris under control of the nitrogen source-regulated formaldehyde dehydrogenase promoter. J. Biotechnol. 2004, 109, 103-113. [CrossRef] [PubMed]

62. Romero, E.; Ferreira, P.; Martínez, Á.T.; Martínez, M.J. New oxidase from Bjerkandera arthroconidial anamorph that oxidizes both phenolic and nonphenolic benzyl alcohols. Biochim. Biophys. Acta-Proteins Proteom. 2009, 1794, 689-697. [CrossRef] [PubMed]

63. Bonet-Ragel, K.; Canet, A.; Benaiges, M.D.; Valero, F. Synthesis of biodiesel from high FFA alperujo oil catalysed by immobilised lipase. Fuel 2015, 161, 12-17. [CrossRef]

64. Bonet-Ragel, K.; Canet, A.; Benaiges, M.D.; Valero, F. Effect of acyl-acceptor stepwise addition strategy using alperujo oil as a substrate in enzymatic biodiesel synthesis. J. Chem. Technol. Biotechnol. 2018, 93, 541-547. [CrossRef]

65. Aymard, C.; Belarbi, A. Kinetics of thermal deactivation of enzymes: A simple three parameters phenomenological model can describe the decay of enzyme activity, irrespectively of the mechanism. Enzym. Microb. Technol. 2000, 27, 612-618. [CrossRef]

66. Canet, A.; Dolors Benaiges, M.; Valero, F. Biodiesel synthesis in a solvent-free system by recombinant Rhizopus oryzae lipase. Study of the catalytic reaction progress. JAOCS J. Am. Oil Chem. Soc. 2014, 91, 1499-1506. [CrossRef] 